\title{
IKERKUTATÁSOK ÉS EPIGENETIKA
}

\section{TWIN RESEARCH AND EPIGENETICS}

\author{
Melicher Dóra \\ $M A, M D, P h D$ \\ Semmelweis Egyetem, Genetikai, Sejt- és Immunbiológiai Intézet, MTA-SE Immun-proteogenomikai Extracelluláris Vezikula \\ Kutatócsoport \\ melicher.dora@med.semmelweis-univ.hu
}

\begin{abstract}
ÖSSZEFOGLALÁS
Vajon miért különböznek az emberek fizikai és pszichológiai jellemzőikben? Hogyan járul hozzá a természet és a környezet például a testmagasság, a szív- és érrendszeri betegségek, a személyiség, a depresszió vagy az intelligencia emberek közti változatosságához? Régóta feltett kérdések ezek, melyek éppúgy foglalkoztatják a laikusokat, mint a filozófusokat vagy tudósokat. Ismert, hogy a külső megjelenést, a fenotípust genetikai tényezők, környezeti hatások és véletlen variációk együttesen alakítják, feltérképezésük és a mögöttes mechanizmusok jobb megértésére törekvés izgalmas kihívás elé állítja a kutatókat. Az egyik legfontosabb aspektus annak felderítése, hogy az egészségi állapotunkat befolyásoló tényezők közül pontosan melyekre lehetünk tudatos hatással, amelyeknek mind az egészségmegőrzés, mind a betegségmegelőzés, mind a kóros irányú folyamatok beavatkozási pontjainak azonosítása szempontjából messzemenő jelentősége van. Ezenfelül egyre inkább fókuszpontba kerül a személyre szabott orvoslás, egyre fokozódó igény a betegségek kezelésének egyénivé tétele, melyhez elengedhetetlen több szempontból is tanulmányozni, vajon a genetikai és a környezeti tényezők milyen módon befolyásolják különböző jellegek megjelenését, miként hatnak egészségre és betegségre. A tudomány fejlődése különböző metodológiák kidolgozását indukálta, és tapasztalati felfedezéseket eredményezett, melyben az ikrek tanulmányozásának fontos szerep jutott, és jut ma is. A cikk az ikervizsgálatok jelenleg alkalmazott módszereiről, és ehhez kapcsolódóan az epigenetika kérdésköréről, valamint az ikerkutatásokhoz füzött jövőbeli várakozásokról kíván áttekintést nyújtani.
\end{abstract}

\section{ABSTRACT}

Why do people differ in their physical and psychological characteristics? How do nature and nurture, factors such as height, cardiovascular diseases, personality, depression or intelligence contribute to the variability between individuals? These questions have long been asked, making researchers, philosophers or common people just as curious. We know that genetic factors, environmental influences and random variations altogether compose our phenotype. The quest to gain a better insight and understanding into those mechanisms has been an exciting challenge for researchers. One of the key aspects is to decipher those factors of our health that we can have a conscious influence on. These are of utmost importance both to health pre- 
servation, disease prevention and also for the identification of possible intervention points in various pathologies. Personalized medicine is gaining ever more ground and in the quest to widen its application it is essential to study how genetic and environmental factors can affect the phenotype, how they influence health and disease. Scientific progress has led to different methodologies and presented empirical findings, to which the study of twins has contributed significantly. The article aims to provide an overview of the currently applied methods in twin research, concerns the related topic of epigenetics and the future perspectives of twin studies.

Kulcsszavak: ikerkutatás, epigenetika, személyre szabott orvoslás, diszkordáns ikrek

Keywords: twin studies, epigenetics, personalized medicine, discordant twins

\section{BEVEZETÉS}

Az ikerkutatások szépsége az eddig feltáratlan tényezők vizsgálatának lehetőségében rejlik, amit többek között az ikrek biológiájából adódó sajátos módszertani logika tesz lehetővé. Az egypetéjü ikrek egy megtermékenyített petesejt osztódásából származnak, így genetikai állományuk közel 100\%-ban azonos (egészen pár évvel ezelőttig még azt gondolták a kutatók, hogy 100\%-os a megegyezés, ám közöttük is vannak egészen apró különbségek, amelyeket később fejtünk majd ki). A kétpetéjü ikrek két megtermékenyített petesejtből fejlődnek, ezáltal génjeik átlagosan fele megegyezik, hasonlóan más, nem egy időpontban született testvérekéhez.

Az orvostudományi témájú vizsgálatok egy csoportja az ikrek DNS sorrendjének egyedi jellemzőit kiválóan fel tudja használni arra, hogy - összehasonlítva az egy- és kétpetéjü ikreket vagy a különböző kórképeket mutató egypetéjủ ikrek eredményeit - megbecsülhessék, vajon az esetleges betegségek kialakulásáért, lefolyásáért milyen mértékben felelősek a genetikai adottságok, és milyen mértékben egyéb más, akár az életmód által is befolyásolható, gyüjtőfogalommal kifejezve, ún. környezeti tényezők.

\section{KLASSZIKUS IKERVIZSGÁLATOK}

A különbözö ikervizsgálati modellek közül az ún. klasszikus ikervizsgálatok rendelkeznek a legnagyobb múlttal, évtizedek óta alkalmazott eszközként szolgálnak az orvosbiológiai, pszichiátriai és viselkedéstudományi kutatásokban egyaránt. A módszer az egypetéjü (monozigóta, $\mathrm{MZ}$ ) és kétpetéjü (dizigóta, DZ) ikrek fenotípusos hasonlóságát összevetve vizsgálja az örökölhetőség és a környezeti hatások befolyását konkordanciaértékek és intraklassz-korreláció számítás segít- 
ségével. Az öröklődő hányad - definíció szerint - azt fejezi ki, hogy a népességben tapasztalt fenotípus-variációkért milyen arányban felelösek a genetikai faktorok variációi. Az öröklődő hányad vagy örökölhetőség egy populációban függ a genetikai és környezeti faktoroktól. A becsléshez a strukturális modellek egy specifikus fenotípus varianciáját három összetevőre osztják: genetikai hatások, ún. közös környezeti és egyedi környezeti hatások. A közös környezeti hatások miatt az ikrek nagyobb hasonlóságot mutathatnak annál, mint ami kizárólag a génállományuk egyezőségéből következne, míg az egyedi környezeti hatások okozhatják az ikrek közötti, eltérő életmódjukból adódó különbségeket. A közös környezet magában foglalja az összes olyan külső tényezőt, amely az ikerpár mindkét tagjára egyszerre hatott, hasonlóvá téve ezzel őket, ide tartozik például a közös anyaméh, a gyermekkori élmények, a korai szocializáció vagy a családi körülmények. Ugyanakkor az egyedi környezet azon faktorokat összesíti, melyeknek csupán az ikerpár egyik tagja volt kitéve, különbözővé téve ezzel őket, például bizonyos vírusfertőzések, balesetek, egyéni életesemények tartozhatnak ide (van Dongen et al., 2012).

Az ikerkutatás e módszere lehetőséget kínál a fenotípust alakító különböző hatások tanulmányozására, a gének és a környezet közvetlen megfigyelése nélkül. Az ok-okozati viszony bizonyítása alapvető kihívást jelent számos tudományos törekvés számára. A pszichológiában, orvostudományban és epidemiológiában az ok-okozati viszony kimutatásához leginkább ideális modellként a randomizált, kettős vak kutatási elrendezést tekintik. Ugyanakkor számos tudományos kérdés esetében ilyen típusú vizsgálat etikai vagy egyéb megvalósíthatósági korlátokba ütközhet. Az ikerkutatások metódusa olyan megközelítést is képvisel, melyben az okozati tényezők hatásai keresztmetszeti adatok alapján tanulmányozhatók. Ennek alapján az ikrek vizsgálatával becsülhetővé válhatnak azon genetikai és környezeti tényezők, melyek a varianciához járulnak hozzá egy bizonyos fenotípus esetében, és ilyen módon okozati viszonyba hozhatók a vizsgált jelenséggel (Røysamb-Tambs, 2016).

A klasszikus ikervizsgálatok mellett az ún. diszkordáns ikervizsgálatokhoz azt a reményt füzik, hogy segítenek a komplex betegségeket együttesen alakító genetikai és környezeti faktorok tekintetében mélyrehatóbb tudást szerezni.

\section{AZ EPIGENETIKA SZEREPE}

Az egypetéjű ikrek, bár egy megtermékenyített petesejtből származnak, és ebből adódóan genetikai állományuk csaknem azonos, mégsem teljesen egyformák, fenotípusukban számos eltérés lehet, a születési súlytól vagy fizikális tulajdonságaiktól kezdve megannyi betegség megnyilvánulásáig mutathatnak különbségeket. A monozigóta ikreknél több esetben láthatunk példát arra, hogy csak a pár 
egyik tagjánál lép fel egy bizonyos kórkép, míg a másiknál ez nem figyelhető meg. A kutatások betegségre diszkordáns monozigóta ikrekként hivatkoznak az ilyen ikerpárokra (Boomsma et al., 2002).

Az ikerkutatásokban gyakran használt konkordancia értéke megmutatja, hogy az ikerpárok hány százaléka azonos az adott tulajdonság tekintetében, míg a diszkordancia értékét a 100\%-ból kivont konkordancia adja. Az egypetéjü ikrek között változó arányú konkordancia és diszkordancia értékeket mértek a legtöbb gyakran elöforduló komplex betegség tekintetében. A becsült konkordancia értékeket 1-es típusú diabétesz esetében 61\%-ra, 2-es típusú diabétesznél 41\%-ra, autizmusnál 58-60\%-ra, skizofrénia esetében 58\%-ra, míg a daganatos megbetegedések esetében 0-16\% értékre becsülték (Castillo-Fernandez et al., 2014).

A betegségek tanulmányozásában a ,genetikán túli” hatásokat vizsgáló kutatások számára kiváló lehetőséget nyújthat a betegségre diszkordáns MZ-ikrek egyedülálló vizsgálati modellje. Az egypetéjü ikrek tanulmányozása lehetővé teszi, hogy bővítsük ismereteinket az epigenetikai hatások betegségekben betöltött szerepéről, a modellből kifolyólag a genetikai faktorok, életkor, nem, anyai hatások, kohort hatások és más potenciális torzító tényezők egyidejü kontrollja mellett.

Felvetődik a kérdés, vajon hogyan történhet meg, hogy egy egypetéjü ikerpár két tagja közül, a közel azonos génállomány dacára, csak az egyik betegszik meg például szívbetegségben, vagy lesz daganatos elváltozása? Mi okozhatja pontosan a köztük lévő különbségeket? Az eltérések hátterében a gének funkciójának, múködésének, úgy is mondhatjuk, ,megszólalásának” megváltozása állhat. Egyes gének ,elcsendesedhetnek”, míg mások bekapcsolódnak (aktiválódnak). A gének tehát nem változnak, ám a müködésük és ezzel az általuk kifejtett hatás is változhat. Ennek mélyére igyekszik ásni egy sokak számára új és rengeteg várakozást keltő tudományág, melynek neve „epigenetika”. A „felett” jelentésü ógörög „epi” előtag arra utal, hogy az információ átkerülése a DNS-szekvencia megváltozása nélkül történik. Epigenetikai történésnek hívhatjuk tehát, ha a gének funkciója anélkül változik meg, hogy maga a DNS-kód, a gén A (adenin), G (guanin), T (timin), C (citozin) betúkódokkal is leírható sora (szekvenciája) megváltozna.

Ahhoz, hogy betekintést nyerjünk az epigenetikai vizsgálatok jelenleg használt eszköztárába, röviden összefoglaljuk az epigenetika fogalomkörét, beleértve a kapcsolódó molekuláris módosításokat.

Az epigenetika az embrionális fejlődés és sejtdifferenciálódás hátterében álló biológiai mechanizmusok tanulmányozásának tudományaként jelent meg a huszadik század első felében (Waddington, 1942). Ma a DNS nukleotid sorrend megváltoztatása nélkül végbemenő, a sejtosztódás általi magi átörökítésként definiálják, és ide sorolnak minden olyan mechanizmust, amely a génexpressziót a DNS-szekvencia módosítása nélkül változtatja meg (Holliday, 1994). Fontos 
hangsúlyozni, hogy a genom kovalens és reverzibilis módosításáról van szó. Az epigenetikai módosulások közül a legátfogóbban napjainkig a DNS-metilációt tanulmányozták. A gének promoter régiójában található $\mathrm{CpG}$-dinukleotidok citozin metilációja általában a génexpresszió gátlásához vezet, míg a gének kódoló részeiben lévő magas szintủ metilációs mintázatot transzkripcionálisan aktív gének esetében figyelték meg. Az epigenetikai módosítások vonatkozásában a DNS-metilációt követően a hisztonmódosulások tanulmányozásának van a legátfogóbb szakirodalma, mely sokféle lehet, beleértve az acetiláció, metiláció, foszforiláció, ubikvitináció, ADP-riboziláció és más módosításokat, és ezeknek a génexpressziót befolyásoló kombinációit. A hisztonvariánsok, az ATP-dependens hisztonátrendező komplexek és a nemkódoló RNS-ek az eddig még kevésbé feltárt epigenetikai módosulások sorához tartoznak.

Az életmódbeli, környezeti faktorok - melybe többek között beletartozik a táplálkozás, mozgás, mérgek, fertőzések, alvás, fény, zene, stressz, lelki hatások, és folytathatnánk a hosszú sort - tehát hatással lehetnek az örökítő anyag megnyilvánulására, géneket aktiválva, illetve inaktiválva, befolyásolva ezzel betegségek kialakulását, azaz sok esetben e tényezők függvénye, hogy egy tulajdonság a fenotípus szintjén manifesztálódik-e vagy sem.

Annak egyik oka, hogy napjainkig az epigenetikai módosítások közül a DNS-metilációs vizsgálatok terjedtek el leginkább, a rendelkezésre álló kifejlesztett módszerek hozzáférhetőségében keresendő. Az EWAS (epigenome-wide association studies) vizsgálatok leggyakrabban használt platformja az Illumina Infinium Human Methylation BeadChip array (HM450 vagy 450k array), amely a genomszintü DNS-metilációt közel 480000 CpG helyen képes mérni. A mai epigenetika tárgyú ikervizsgálatok döntö hányada is ezt a módszert alkalmazza (Craig-Saffery, 2015).

Az epigenetikai módosulások és fenotípus-variációk közti összefüggések legnagyobb részét egymástól teljesen független alanyok részvételével végzett tanulmányok írták le. A dohányzás a DNS-metilációt módosítani képes ismert környezeti tényezők egy szemléletes példáját nyújtja (Zeilinger et al., 2013). Az epigenetikai módosításokkal kapcsolatos érdekes megfigyelések egyike, hogy több, dohányzással asszociált DNS-szakasz metiláltsági szintje általában megegyezett a dohányzásról leszokott és a sosem dohányzott vizsgálati alanyok esetében, amelyből a kutatók azt a következtetést vonták le, hogy a dohányzásról való leszokás a metilációs mintázat visszarendeződését vonhatja maga után, rávilágítva ezzel az epigenetikai módosítások reverzibilis természetére. A dohányzás mellett számos más környezeti faktort hoztak összefüggésbe a DNS-metilációs profil megváltozásával, beleértve az étkezési szokásokat, a környezeti mérgeknek, hőmérséklet-ingadozásnak és más tényezőknek való kitettséget (bár e vizsgálati eredmények többségének humán kísérletekkel való további alátámasztása még szükséges) (Feil-Fraga, 2011). Ám számos olyan kutatás is született, amely 
ikrek epigenetikai profilját vizsgálta egészséges fejlődéssel, öregedéssel és különböző betegségekkel összefüggésben.

Az epigenetikai ikerkutatások néhány sarkalatos kérdés vizsgálatában segíthetnek: Vajon az epigenetikai változások mennyiben örökölhetők? Milyen mértékủ variációt mutat az epigenetikai öröklődés a genom szintjén? Hogyan járulnak hozzá az epigenetikai faktorok a komplex fenotípusokhoz? Továbbra is számos nyitott kérdés övezi a témakört, de elmondható, hogy az egypetéjü ikrek mind egy ikerpáron belüli (ún. intra-pár), mind ikerpárok közötti (ún. inter-pár) összehasonlítása a genomikai és epigenomikai kutatások páratlanul fontos modelljei közé tartozhatnak (Tan et al., 2013). Az új technológiai vívmányok eszközrendszerként szolgálhatnak annak becslésében, milyen szinten hasonlítanak vagy különböznek az egypetéjü ikrek azon molekuláris folyamatok szintjén, melyek fenotípusuk hasonlóságához vagy eltéréseihez járulhatnak hozzá (BellSpector, 2011).

Egypetéjü ikrek epigenetikai profiljának eltéréseire fiatalabb és idősebb korcsoportokban egyaránt találtak bizonyítékokat (Fraga et al., 2005; Wong et al., 2010). A DNS-metiláció és a génexpresszió különbségei már újszülött MZ-ikrekben is megmutatkozhatnak, a környezeti és sztochasztikus tényezők hatása in utero kezdődik, és egy életen át tart (Bell-Spector, 2011).

2005-ben Mario F. Fraga és szerzőtársai írták le elöször, hogy az egypetéjü ikrekben életük során eltérő epigenetikai módosulások alakulnak ki. MZ-ikerpárok perifériás limfocitáinak metil-citozin és hiszton-acetilációs szintjét összehasonlítva azt találták, hogy az idősek, illetve kevesebb időt együtt töltő vagy eltérő egészségi állapottal, betegségtörténettel bíró ikerpárok nagyobb mértékü különbözőséget mutattak mindkét általuk vizsgált epigenetikai módosulás tekintetében. Zachary Kaminsky és szerzőtársai három különböző szövettípus (fehérvérsejtek, bukkális hámsejtek és bélbiopszia során kinyert sejtek) vizsgálata során szintén a DNS-metiláció eltérő mértékét figyelték meg ikerpárok egyes tagjai között, továbbá nagyobb fokú egyezést állapítottak meg az egypetéjü ikerpárok DNS-metilációs szintjében, mint a kétpetéjű ikerpárokéban (Kaminsky et al., 2009). Ahogyan tehát az MZ-ikrek felnőttkori életmódja eltér, valószínüleg ezzel párhuzamosan epigenomjuk is eltéróen változik.

Alábbiakban röviden sorra vesszük az epigenetikai eltérések lehetséges forrásait.

Az életmódbeli tényezők mint környezeti hatások mellett az egypetéjü ikrek között kialakuló különbségek további feltételezett oka szintén a környezeti tényezőkben keresendő. Az MZ-ikrek a placenta kialakulásával és vaszkularizációjával összefüggően eltérő mértékben juthatnak táplálékhoz magzati fejlődésük során. Mivel az MZ-ikrek méhen belüli környezete különbözhet, valószínúsíthetö, hogy intrautein fejlődésük hozzájárul a kialakuló epigenetikai eltéréseikhez. Az egypetéjü ikreket külön csoportokra lehet osztani aszerint, hogy egy 
közös placenta (monochorion) vagy külön placenta (dichorion) táplálta őket méhen belüli fejlődésük során, az ezzel kapcsolatos tanulmányozásokat összefoglaló néven chorionicitás vizsgálatoknak nevezik. Kutatási eredmények szerint a chorionicitásnak jelentősége lehet az epigenetikai mintázat kialakulásában. Azt találták, hogy a monochoriális ikerpárok jobban különböztek DNS-metilációs profiljukban, összevetve a dichoriális ikerpárokban kapott eredményekkel (Kaminsky et al., 2009; Gordon et al., 2012). Egyes feltételezések szerint a monochoriális ikrek azért lehetnek eltéröbbek, mert nagyobb eséllyel versenyeztek a tápanyagért magzati fejlődésük során (Gordon et al., 2012). Mindkét tanulmány kis mintán alapult, így további ismétlést igényel, ám eredményeik igen fontos új szempontokat vetnek fel. Meg kell említeni továbbá, hogy az ikrek között vaszkuláris kapcsolatokon keresztül in utero magzati vércsere történhet, így a chorionicitás részben köthető az MZ-ikrekben lehetséges kimérizmus jelenségéhez is (Castillo-Fernandez et al., 2014).

Az epigenetikai jelölők kialakításának és fenntartásának egyedi mechanizmusa szintén magyarázatul szolgálhat az egypetéjü ikerpárok tagjai között észlelhető epigenetikai eltérésekre. Ahogy említettük, a DNS-metiláció napjainkban az egyik leggyakrabban vizsgált epigenetikai módosítás, melyet DNS metiltranszferáz enzimek végeznek. Az általuk kialakított módosítások a szomatikus sejtek osztódásával átörökítődnek, mely folyamat során ún. epimutációk (az epigenetikai jelölőkben kialakuló eltérések) alakulhatnak ki. (A DNMT3a és DNMT3b de novo metiltranszferázok, melyek müködésüket az embrionális fejlődés alatt, a gametogenezis során fejtik ki, míg a DNMT1 fenntartó metiltranszferáz.) Mivel a metil-citozinok a DNS-replikáció során nem másolódnak át, az újonnan szintetizált DNS-szálon nem találhatóak meg ezek az epigenetikai jelölők. A DNMT1 nevủ fenntartó metiltranszferáz enzim a DNS-molekula metilált szálát használja szubsztrátként, és metilálja a komplementer szál megfelelö molekuláit. A sejtosztódáskor fellépő és a további osztódások során átörökített epimutációk feltehetően a DNMT1 fenntartó metiltranszferáz esetleges hibás müködéséből adódhatnak. Egyes megfigyelések szerint a DNMT1 a metilációs helyek 4-5\%-át figyelmen kívül hagyja, és de novo metilációt végez egyes sủrün metilált régiók közelében (Vilkaitis et al., 2005). Ugyan az MZ-ikrekben megfigyelt diszkordanciát legnagyobb részben a környezeti tényezők különbözőségével magyarázzák, ám kiemelendö, hogy a nehezen feltérképezhető sztochasztikus történések szintén szereppel bírhatnak.

Bár az MZ-ikreket gyakran genetikailag megegyezőként említik, a különbözőségek okai között posztzigotikus módosítások is szerepet kaphatnak. A korai fejlődés alatt kialakuló szomatikus pontmutációk egyes ikerpárokra vonatkoztatva $1,2 \times 10^{-7}$ /bázispár gyakorisággal fordulhatnak elö. Hasonlóan, szomatikus kópiaszám-variációkat (copy number variation) figyeltek meg mind egészséges konkordáns, mind betegségekre diszkordáns MZ-ikerpárok esetében. A genetikai 
variáció epigenetikai jelölőkre gyakorolt hatását támasztja alá, hogy összefüggést találtak az egy nukleotid polimorfizmusok (single nucleotide polymorphism, SNP) specifikus génvariációi és egyes DNS-metilációs helyek között. Ebből adódóan feltételezik, hogy az MZ-ikrekben kialakuló szomatikus mutációk vagy kópiaszám-variációk sejt- és szövetspecifikus epimutációkhoz vezethetnek (Castillo-Fernandez et al., 2014).

\section{DISZKORDÁNS IKERVIZSGÁLATOK}

Fontos megjegyezni, hogy bár az epigenetikai variációt nagyszámú ikermintán eddig még nem vizsgálták, több kisebb kutatás tapasztalataiból kiindulva a diszkordáns ikervizsgálatokhoz nagy reményeket füznek. Ilyen vizsgálatok születtek az Alzheimer-kór, autizmus, bipoláris zavar, születési súly, daganatos megbetegedések és szisztémás lupusz eritematózus (SLE) témaköreiben (Castillo-Fernandez et al., 2014).

Az alábbiakban néhány példát említünk. SLE diszkordáns egypetéjü ikrekben a DNS-metilációs szint globális csökkenését figyelték meg az SLE-vel érintett ikertag esetében, továbbá regionális DNS-metilációs elváltozásokat találtak 49, főképp immunfunkciót szabályozó génben. Emellett több gén, melynek hipometilációját mérték az SLE-vel érintett ikerben, fokozott expressziót mutatott az egészséges ikertagnál mért értékhez képest (Javierre et al., 2010).

Asztmára diszkordáns egypetéjü ikreket vizsgálva arra próbáltak választ adni, hogy vajon a T-sejteket érintő epigenetikai modifikációk kapcsolatba hozhatók-e az asztmával. A diszkordáns ikerpárok bevonásával végzett vizsgálat regulátoros (Treg) és effektor T-sejt (Teff) alcsoportokat jellemzett, mely során sejtfunkció, fehérje- és génexpresszió, valamint a FOXP3 és IFN $\gamma$ lókuszok CpG metilációja került meghatározásra. Az asztmával diagnosztizált ikertagok T-sejtjeit összehasonlítva az asztmás betegséggel nem érintett ikertestvérükkel, csökkent FOXP3 fehérjeexpressziót és visszaesett Treg-funkciót figyeltek meg, mely a FOXP3 lókusz növekedett CpG metilációs szintjével párosult. Ezzel párhuzamosan az effektor T-sejtek esetében az IFN $\gamma$ lókusz növekedett metilációs szintjét állapították meg, továbbá csökkent IFN $\gamma$ expressziót és redukált effektor T-sejt funkciót találtak, amikor az asztmás ikrek eredményeit tünetmentes testvéreikhez hasonlították. Emellett a passzív dohányzás hatásai mind a Treg-, mind a Teff-sejtek transzkripciós szintű változásával társult az asztmások körében. A vizsgálat eredményei az asztmára diszkordáns MZ-ikrek eltérő T-sejt funkcióira világítottak rá, melyek szabályozásában a DNS-metiláció szerepét mutatták ki (Runyon et al., 2012).

Megállapították, hogy a DNS-metiláció és génexpresszió integrált vizsgálata különösen értékes segítséget nyújthat azon lókuszok azonosításában, melyeket 
érintő epigenetikai szabályozás betegséggel való összefüggést hordozhat (van Dongen et al., 2012).

Az MZ-ikrek fenotípusbeli eltérésének hátterében álló lehetséges epigenetikai variációk további példáját szemlélteti egy 1997-ben született egypetéjủ ikerpár esete, melynek egyik tagja egészségesen, másik tagja súlyos gerinc-rendellenességgel jött világra. A kórkép egy, az egerekben megfigyelt, AXIN1-gén mutációjával járó állapotra emlékeztetett. Az ikerpár mindkét tagjában pontmutációt állapítottak meg az AXIN1-génben, azonban a betegségben szenvedö ikertag AXIN1-gén promoterének $\mathrm{CpG}$-helyein emelkedett metilációs mintázat volt megfigyelhetö, összevetve az egészséges ikertestvérében mért metilációs szinttel. A kutatók következtetése szerint a metilációs eltérés vezethetett a rendellenesség kialakulásához (Oates et al., 2006).

A nemkódoló RNS-ek, microRNS-ek szerepe meglehetősen feltáratlan, napról napra új felfedezések születnek, és néhány ikervizsgálat is foglalkozott a témával. Autizmusra diszkordáns MZ-ikrek és testvérpárok vizsgálata során limfoblasztoid sejtvonalak miRNS-expresszióját mérték, és számos miRNS-transzkriptum eltérő szabályozását figyelték meg. A miRNS-adatok és mRNS-expressziós adatok összevetésével azt találták, hogy a miRNS-expresszió diszregulációja közrejátszhat a célgén-expresszió megváltozásában, mely így hozzájárulhat az autizmus betegség patológiájához (Sarachana et al., 2010). Lupusz nefritiszre diszkordáns MZ-ikrekben szintén számos miRNS eltérő expresszióját figyelték meg. Eredetileg a legfontosabb miRNS-ek célgénjei között olyan géneket találtak, melyeknek szerepük volt az interferon szignalizációban. Mindezen tanulmányok azt jelzik, hogy a diszkordáns MZ-ikermodell értékes megközelítésként szolgálhat a miRNS-expresszió komplex betegségekben betöltött szerepének kutatásában is (van Dongen et al., 2012).

Az ikreket már az ürkutatásban is bevetették. Az Amerikai Ürkutatási Hivatal (NASA) 2015-2016-ban különleges és rekord hosszúságú ürutazást hajtott végre, amelyhez rendkívül fontos és egyedülálló ikerkutatás kapcsolódik, melynek során egy egypetéjü ürhajós ikerpárt vizsgálnak. A kutatók többek között azokra az epigenetikai elváltozásokra igyekeznek fényt deríteni, amelyek az egy évet a Nemzetközi Ürállomáson töltött Scott Kelly testében végbementek. Az asztronauta ürrepülése elött, közben és után is végeztek méréseket, melyeket az ugyancsak ürhajós és nagyon hasonló életúttal rendelkezö ikertestvérének, Mark Kellynek adataival vetnek össze. Jelenleg a világ legfejlettebb technológiáival dolgozó, élenjáró laboratóriumai értékelik az általános fiziológiai, pszichológiai, mikrobiológiai, epigenetikai molekuláris változásokat is magukban foglaló kísérleteket, amelyek eredményeit integrált tudományos közlemény formájában ígérik még ebben az évben nyilvánosságra hozni. 


\section{A JÖVŐ VÁRAKOZÁSAI}

Az epigenetika, a fejlődésbiológiában betöltött kulcsszerepén túlmenően, az epidemiológia számára is nagy reményeket keltő kutatási irány, segítségével számos betegség hátterében álló biológiai mechanizmusok feltárására kerülhet sor, emellett betegségek kimutatását segítő, illetve azok előrehaladását követő biomarkerek felfedezéséhez egyaránt hozzájárulhat. Az MZ-ikrek epigenetikai összehasonlítása, valamint a DNS-metiláció és más módosítások örökölhetőségét vizsgáló tanulmányok rávilágítanak arra, hogy a legtöbb epigenetikai variabilitás egyedi lehet az egyén számára. A jövőben az epigenetika szerepe kiváltképp fontosnak mutatkozhat a P4-medicina (személyre szabott, prediktív, preventív és részvételen alapuló) terén mint stabil, mégis potenciálisan reverzibilis molekuláris mechanizmus (Castillo-Fernandez et al., 2014).

Az elkövetkező években a különböző fenotípusokról nyert kiterjedt longitudinális információk - összekapcsolva világméretű ikerregiszterek által összegyüjtött biológiai mintákkal - kimagasló erőforrássá válhatnak nagyszabású molekuláris vizsgálatokhoz. Az újgenerációs szekvenálás eszközrendszere rendkívül felgyorsítja majd a genomszintủ SNP-k, a CNV-k és epigenetikai variációk kimutatását, további fontos szerepet rendelve a diszkordáns ikermódszertannak a humán genetikai vizsgálatok terén (van Dongen et al., 2012).

Az ikervizsgálatok eszközrendszert nyújtanak egy betegség vagy tulajdonság létrejöttében szerepet játszó genetikai és környezeti tényezők arányának becslésében, valamint a molekuláris genetikai és gén-környezet interakciós vizsgálatokban, továbbá fontos szerepük van a családi szocializáció szerepének feltárásában is. Többek között a klasszikus ikervizsgálatok világítottak rá arra a fontos tényre is, hogy a gének aktivitási, azaz epigenetikai mintázata szintén öröklödhet, ezzel hangsúlyozva, hogy a nagyszülők, szülők életmódjának káros következményei átörökíthetők az utódokra. Az epigenetikai folyamatok egy részének visszafordítható természete az életmód és annak megváltoztatásának jelentős egészségügyi hatásaira hívják fel a figyelmet.

Ahogyan más módszertanok és tudományos megközelítések esetében, ezen a területen is több aggály és kétség merülhet fel, ugyanakkor a föbb megállapítások megalapozottságát egy sor megismételt eredmény támasztja alá. A kutatók reményei szerint az ikerkutatások nemzetközi és nemzeti szinten egyaránt tovább gyarapodhatnak és bővülhetnek, lehetővé téve ezzel akár a molekuláris genetikai, pszichológiai, orvostudományi vagy epidemiológiai területeken nyert új információk integrált értelmezését.

Összefoglalóan elmondható, hogy az egypetéjủ és kétpetéjü ikrek tanulmányozása lehetőséget kínál, hogy eddig megválaszolatlan tudományos kérdésekre kaphassunk választ, akár családi, akár társadalmi vagy orvostudományi területeken. Az ikrek segítségével számos témakörben nyílhat lehetőség új megfigyelések, 
feltáratlan összefüggések megvilágítására, melyek sok más mellett látókörünk szélesítéséhez, egészségünk megőrzéséhez, betegségek megelözéséhez, hatásosabb gyógymódok fejlesztéséhez segíthetnek hozzá.

\section{IRODALOM}

Bell, J. T. - Spector, T. D. (2011): A Twin Approach to Unraveling Epigenetics. Trends in Genetics, 27, 3, 116-125. DOI: 10.1016/j.tig.2010.12.005, https://bit.ly/2WTbURT

Boomsma, D. - Busjahn, A. - Peltonen, L. (2002): Classical Twin Studies and Beyond. Nature Reviews Genetics, 3, 11, 872-882. DOI: 10.1038/nrg932, https://www.researchgate.net/publication/11050709_Classical_Twin_Studies_and_Beyond

Castillo-Fernandez, J. E. - - Spector, T. D. - Bell, J. T. (2014): Epigenetics of Discordant Monozygotic Twins: Implications for Disease. Genome Medicine, 6, DOI: 10.1186/s13073-014-0060-z, https://www.ncbi.nlm.nih.gov/pmc/articles/PMC4254430/pdf/13073_2014_Article_60.pdf

Craig, J. M. - Saffery, R. (2015): The Power of Two: Epigenetics and Twins. Twin Research and Human Genetics, 18, 6, 621-622. DOI: 10.1017/thg.2015.90, https://www.researchgate.net/publication/292843778_The_Power_of_Two_Epigenetics_and_Twins

van Dongen, J. - Slagboom, P. E. - Draisma, H. H. et al. (2012): The Continuing Value of Twin Studies in the Omics Era. Nature Reviews Genetics, 13, 9, 640-653. DOI: 10.1038/nrg3243, https://www.researchgate.net/publication/230588947_The_continuing_value_of_twin_studies_in_the_omics_era

Feil, R. - Fraga, M. F. (2011): Epigenetics and the Environment: Emerging Patterns and Implications. Nature Reviews Genetics, 13, 2, 97-109. DOI: 10.1038/nrg3142, https://www.researchgate.net/publication/51979144_Epigenetics_and_the_environment_Emerging_patterns_and_ implications

Fraga, M. F. - Ballestar, E. - Paz, M. F. et al. (2005): Epigenetic Differences Arise during the Lifetime of Monozygotic Twins. Proceedings of the National Academy of Sciences of the USA, 102, 30, 10604-10609. DOI: 10.1073/pnas.0500398102, https://www.pnas.org/content $/ 102 / 30 / 10604$

Gordon, L. - Joo, J. E. - Powell, J. E. et al. (2012): Neonatal DNA Methylation Profile in Human Twins Is Specified by a Complex Interplay between Intrauterine Environmental and Genetic Factors, Subject to Tissue-specific Influence. Genome Research, 22, 8, 1395-1406. DOI: 10.1101/gr.136598.111, https://www.ncbi.nlm.nih.gov/pmc/articles/PMC3409253/

Holliday, R. (1994): Epigenetics: An Overview. Developmental Genet, 15, 6, 453-457. DOI: 10.1002/dvg.1020150602, https://www.researchgate.net/publication/5847725_Epigenetics_A_ Historical_Overview

Javierre, B. M. - Fernandez, A. F. - Richter, J. et al. (2010): Changes in the Pattern of DNA Methylation Associate with Twin Discordance in Systemic Lupus Erythematosus. Genome Research, 20, 2, 170-179. DOI: 10.1101/gr.100289.109, https://www.ncbi.nlm.nih.gov/pmc/articles/PMC2813473/

Kaminsky, Z. A. - Tang, T. - Wang, S. C. et al. (2009): DNA Methylation Profiles in Monozygotic and Dizygotic Twins. Nature Genetics, 41, 2, 240-245. DOI: 10.1038/ng.286, https://www. researchgate.net/publication/23798814_DNA_methylation_profiles_in_monozygotic_and_ dizygotic_twins

Oates, N. A. - van Vliet, J. - Duffy, D. L. et al. (2006): Increased DNA Methylation at the AXIN1 Gene in a Monozygotic Twin from a Pair Discordant for a Caudal Duplication Anomaly. Amer- 
ican Journal of Human Genetics, 79, 1, 155-162. DOI: 10.1086/505031, https://www.cell.com/ ajhg/fulltext/S0002-9297(07)60003-2

Røysamb, E. - Tambs, K. (2016): The Beauty, Logic and Limitations of Twin Studies. Norsk Epidemiologi, 26, 1-2. https://doi.org/10.5324/nje.v26i1-2.2014, https://www.researchgate.net/publication/305516297_The beauty_logic_and_limitations_of_twin_studies

Runyon, R. S. - Cachola, L. M. - Rajeshuni, N. et al. (2012): Asthma Discordance in Twins Is Linked to Epigenetic Modifications of T Cells. PLOS ONE, 7, 11, e48796. DOI: 10.1371/journal. pone.0048796, https://journals.plos.org/plosone/article?id=10.1371/journal.pone.0048796

Sarachana, T. - Zhou, R. - Chen, G. et al. (2010): Investigation of Post-transcriptional Gene Regulatory Networks Associated with Autism Spectrum Disorders by microRNA Expression Profiling of Lymphoblastoid Cell Lines. Genome Medicine, 2, 4, 23. DOI: 10.1186/gm144, https:// genomemedicine.biomedcentral.com/articles/10.1186/gm144

Tan, Q. - Christiansen, L. - Thomassen, M. et al. (2013): Twins for Epigenetic Studies of Human Aging and Development. Ageing Research Reviews, 12, 1, 182-187. DOI: 10.1016/j. arr.2012.06.004, https://www.ncbi.nlm.nih.gov/pmc/articles/PMC3509237/

Vilkaitis, G. - Suetake, I. - Klimasauskas, S. et al. (2005): Processive Methylation of Hemimethylated CpG Sites by Mouse Dnmt1 DNA Methyltransferase. Journal of Biological Chemistry, 280, 1, 64-72. DOI: 10.1074/jbc.M411126200, http://www.jbc.org/content/280/1/64.long

Waddington, C. H. (1942): The Epigenotype. Endeavour, 1, 18-20. DOI: 10.1093/ije/dyr184, https:// bit.ly/2KEBPGu

Wong, C. C. - Caspi, A. - Williams, B. et al. (2010): A Longitudinal Study of Epigenetic Variation in Twins. Epigenetics, 5, 6, 516-526. DOI: 10.4161/epi.5.6.12226, https://www.tandfonline. com/doi/full/10.4161/epi.5.6.12226

Zeilinger, S. - Kühnel, B. - Klopp, N. et al. (2013): Tobacco Smoking Leads to Extensive Genome-wide Changes in DNA Methylation. PLOS ONE, 8, 5, e63812. DOI: 10.1371/journal. pone.0063812, https://journals.plos.org/plosone/article?id=10.1371/journal.pone.0063812 